\title{
Patient comorbidities as risk factors for surgical site infection in gynecologic and obstetric surgery
}

\begin{abstract}
Surgical site infections (SSIs) are infections that develop from a wound created by an invasive surgical procedure. Hospital-acquired infections are an indicator of hospital quality and also evaluate the efficiency of nosocomial infection committees. Numerous risk factors contribute to their development. So, in order to prevent SSIs, they must be identified and controlled in a timely manner.
\end{abstract}

Objective: determine the frequency of comorbidities in hospitalized patients with surgical site infection diagnosis at the Gyneco-Pediatrics Hospital No. 31 of IMSS in Mexicali, Baja California

Material and methods: a retrospective, cross-sectional and descriptive study was carried out in hospitalized patients diagnosed with infected gynecological or obstetric wounds during a one year period. Descriptive statistical analysis was done using SPSS v21.

Results: a total of 95 cases were recorded. The mean age was $36.12 \pm 13.29$ years. We found that $43.2 \%$ ) were smokers before their surgery. The abdomen was the surgical site that presented the highest frequency $(81.1 \%)$ of infection. The most frequent comorbidities were obesity $(69.5 \%)$ and hypertension $(41.1 \%)$. The hospital stay averaged $4.5 \pm 2.1$ days.

Conclusion: Obesity and hypertension were the most frequent comorbidities associated with surgical wound infection, similar to that reported worldwide. Therefore, in primary care, it is very important to identify the patients with existing comorbidities who are going to be subjected to a surgical procedure in order to prevent SSIs.

Keywords: surgical site infection, postsurgical infection, risk factors, gynecologic surgery, obstetric surgery
Volume 3 Issue 2 - 2019

\author{
Mara Paulina Ibarra Mejía,' Jesús María Félix \\ Verduzco, ${ }^{2}$ ME Leticia López López, ${ }^{3}$ María \\ Elena Haro Acosta, ${ }^{4}$ Joan Dautt Silva ${ }^{5}$ \\ 'Family Medicine, Family Medical Unit No.28 of the Mexican \\ Institute of Social Security (IMSS), Mexico \\ ${ }^{2}$ Obstetrician-gynecologist, Gynecology-Pediatrics and Family \\ Medicine Hospital No. 3 I of IMSS, Mexico \\ ${ }^{3}$ Gynecology-Pediatrics and Family Medicine Hospital No. 31 of \\ IMSS, Mexico \\ ${ }^{4} \mathrm{DSc}$, Pediatrician and Teacher in Universidad Autónoma de Baja \\ California in Baja California, Mexico \\ ${ }^{5}$ Medical intern, Gynecology-Pediatrics and Family Medicine \\ Hospital No. 3 I of IMSS, Mexico
}

\begin{abstract}
Correspondence: María Elena Haro Acosta, Dr. Humberto Torres Sangines Street. S/N. Centro Cívico, CP 21000, Mexicali, Baja California, Mexico, Email lenaharo@live.com.mx
\end{abstract}

Received: April 04, 2019| Published: April 16, 2019

\section{Introduction}

Surgical site infections (SSIs) are infections of the incision or organ or space that occur within 30 days after a surgery. Their diagnoses need a positive culture obtained from the incision's fluid or tissue. Clinically, there may be purulent drainage, fever, pain, edema, hyperemia or even an abscess. The diagnosis can also be made if there is evidence of deep infection during the physical examination, histopathological or radiological examination. ${ }^{1}$ According to the latest guideline made by the Centers for Disease Control and Prevention (CDC), SSIs complicated approximately $1.9 \%$ of surgical procedures in the United States. Nonetheless, the number of SSIs is likely to be miscalculated given that approximately $50 \%$ of them become evident after discharge. ${ }^{2}$ This complication prolongs hospital stays and increases mortality, economic, and social costs. Yearly, at a regular prevalence, SSIs generate a need for 2,000 extra hospitalizations, each of them with an average of eight extra days. ${ }^{3}$ The risk factors to develop an SSI can be grouped in three categories: ${ }^{4}$

\section{Patient-dependent}

\section{Surgical-dependent}

III. Miscellaneous: post-operative care, pre-surgical hospital stay, drainage functionality, etc.

The main patient-dependent factors are comorbidities and lifestyle choices, such as: obesity, diabetes, cirrhosis, cancer, alcoholism, smoking, nutrition and the immune system. Table 1 summarizes the mechanisms by which these factors contribute to SSIs..$^{5-8}$ Surgicaldependent risk factors vary from the date in which it is performed, its duration as well as the duration of postoperative period. Prolonged hospital stay has been classically associated with SSIs. However, nowadays, $75 \%$ of the surgical activity is ambulatory, which under diagnoses the SSI that will be developed in the patient's home. This is predisposed by the preoperative colonization of mucous membranes, since it has been shown that between $20-30 \%$ of the population carries S. aureus in their nasal mucosa. ${ }^{7}$ Several studies have established that the season of the year that most often results in SSI is summer, mainly due to the temperature and humidity that these months present. ${ }^{9,10}$ SSIs continue to be a delicate problem that represents a considerable burden on the health system. Early identification, together with an immediate, correct and effective intervention, is important in order to reduce its economic and health-related consequences, especially in the context of increasing antibiotic resistance. ${ }^{11}$ Taking into consideration that factors associated to SSI development have already been identified, first level health care must detect patient comorbidities and apply measures to modify, control or eliminate them. Locally, the frequency of comorbidities in patients with SSI is unknown; so, the objective of this study was to identify their prevalence in hospitalized patients with SSI diagnosis.

\section{Material and methods}

This was a descriptive, observational, cross-sectional and retrospective study, in which the files of hospitalized patients who presented surgical site infections during the 2015-2016 in the Obstetrics-Gynecology and Pediatrics Hospital No. 31 of the Mexican Institute of Social Security (IMSS) in Mexicali, Baja California. After authorization by the Local Research Committee and the corresponding hospital authorities, we carried out an exhaustive search in the registry of the clinical file of our institution, locating the files with diagnosis of 
SSI (ICD-10 O86.0 and T81.4). All of the medical records of patients who were hospitalized and who presented SSI during the study period were included. Sampling was non-probabilistic. We excluded files that had incomplete information. Patient data was collected in a record sheet that included: age, education level, site of the surgical infection, comorbidities, and days of hospital stay. After the database was complete, it was imported into the statistical program SPSS v21 for its analysis. Descriptive statistics were used with measures of central tendency, frequencies and percentages. This research meets the requirements appointed by the Declaration of Helsinki and Mexico's Health Law regarding research. Given that this was a retrospective study, informed written consent was waived; nevertheless, patient confidentiality was kept.

Table I Mechanisms and risk factors of SSI

\begin{tabular}{|c|c|}
\hline Risk factor & Mechanism \\
\hline \multirow[t]{3}{*}{ Obesity } & $\begin{array}{l}\text { If the panniculus adiposus measures } \geq 3.5 \mathrm{~cm} \text {, it has less } \\
\text { blood flow, leading to ischemia }\end{array}$ \\
\hline & Difficulty to close wound edges and prevent dead spaces \\
\hline & Increases surgical time \\
\hline \multirow[t]{3}{*}{ Diabetes } & Microangiopathy \\
\hline & Dysfunction of humoral immunity \\
\hline & Pseudohypoxia induced by hyperglycemia \\
\hline \multirow[t]{2}{*}{ Cancer } & Nutritional and immunological alterations \\
\hline & $\begin{array}{l}\text { Chemotherapy or prior radiotherapy predispose to } \\
\text { inoculation of mixed (aerobic and anaerobic) organisms }\end{array}$ \\
\hline \multirow[t]{2}{*}{ Cirrhosis } & Nutritional, immunological, hematological alterations \\
\hline & Hyperbilirubinemia aggravates leukocyte dysfunction \\
\hline \multirow[t]{2}{*}{ Alcoholism } & $\begin{array}{l}\text { Decreased production of vitamin K-dependent coagulation } \\
\text { factors }\end{array}$ \\
\hline & $\begin{array}{l}\text { Alteration in the formation of proteins with the consequent } \\
\text { malnutrition }\end{array}$ \\
\hline Smoking & Inhibition of macrophage movement \\
\hline Nutrition & $\begin{array}{l}\text { Deficient nutritional status is associated with delayed } \\
\text { healing }\end{array}$ \\
\hline $\begin{array}{l}\text { I m m u n e } \\
\text { system }\end{array}$ & $\begin{array}{l}\text { Bad response to the usual microbial colonization of the } \\
\text { surgical wound }\end{array}$ \\
\hline
\end{tabular}

\section{Results}

The sample consisted of 95 patients who were hospitalized and presented surgical site infection in the years 2015-2016. The mean age was $36.12 \pm 13.29$ years. The most frequent age group was $26-35$ years. Regarding their level of education, high school was the highest degree achieved in most of the patients (47.4\%). Almost half of the patients $(43.2 \%)$ had a history of smoking prior to their surgery. The most frequent comorbidity was obesity $(69.5 \%)$, followed by hypertension (41.1\%). The frequency of the other characteristics included in this study can be seen in Table 2. Regarding the characteristics of the surgery, the distribution by season was almost the same, with autumn being the one with the highest frequency of SSI. This and other characteristics can be seen in Table 3. The abdomen was the surgical site that presented the highest $(81.1 \%)$ frequency of infection. The average hospital stay was $4.5 \pm 2.1$ days. The majority $(42.1 \%)$ of the patients were hospitalized for three days, followed by $23.2 \%$ who stayed for four days.
Table 2 Characteristics of the study population

\begin{tabular}{|c|c|c|}
\hline Characteristic & $\begin{array}{l}\text { Frequency } \\
(n=95)\end{array}$ & $\begin{array}{l}\text { Percentage of total } \\
\text { population (\%) }\end{array}$ \\
\hline Age & \multicolumn{2}{|c|}{ Mean: $36.12 \pm 13.29$ years } \\
\hline \multicolumn{3}{|l|}{ Education grade } \\
\hline $\begin{array}{l}\text { Elementary } \\
\text { school }\end{array}$ & 11 & 11.6 \\
\hline Middle school & 45 & 47.3 \\
\hline High school & 30 & 31.6 \\
\hline Graduate school & 9 & 9.5 \\
\hline \multicolumn{3}{|l|}{ Smoker } \\
\hline Yes & $4 I$ & 43.2 \\
\hline No & 54 & 56.8 \\
\hline \multicolumn{3}{|l|}{ Obesity } \\
\hline Yes & 66 & 69.5 \\
\hline No & 29 & 30.5 \\
\hline \multicolumn{3}{|l|}{ Hypertension } \\
\hline Yes & 39 & 41.1 \\
\hline No & 56 & 58.9 \\
\hline \multicolumn{3}{|l|}{ Diabetes } \\
\hline Yes & 31 & 32.6 \\
\hline No & 64 & 67.4 \\
\hline \multicolumn{3}{|l|}{ Cancer } \\
\hline Yes & 5 & 5.3 \\
\hline No & 90 & 94.7 \\
\hline
\end{tabular}

$\mathrm{SD}$, standard deviation; $\mathrm{n}$, number; \%, percentage

Table 3 Characteristics of surgery and outcomes

\begin{tabular}{lll}
\hline Characteristic & $\begin{array}{l}\text { Frequency } \\
(\mathbf{n}=95)\end{array}$ & $\begin{array}{l}\text { Percentage of total } \\
\text { population (\%) }\end{array}$ \\
\hline \multicolumn{2}{l}{ Season of the year } & \\
Spring & 23 & 24.2 \\
Summer & 23 & 24.2 \\
Fall & 27 & 28.4 \\
Winter & 22 & 23.2 \\
Site of infection & & \\
Abdomen & 77 & 81.1 \\
Vagina & 8 & 8.4 \\
Vaginal vault & 4 & 4.2 \\
Breast & 6 & 6.3 \\
Length of hospital & Mean: $4.5 \pm 2.1$ days \\
stay
\end{tabular}

\section{Discussion}

In the present study, the average age was $36.12 \pm 13.29$ years, similar to that reported in the study conducted in Africa. ${ }^{12}$ In contrast, the study conducted in Mexico in 2002, the average age was much lower, averaging $27.42 \pm 9.5$ years. ${ }^{13}$ The highest level of school achieved was middle school in the majority of patients, a degree higher than the cohort 
in the study conducted by Castro et al. in $2010,{ }^{14}$ where $57.1 \%$ of their patients only completed elementary school. However, the percentage of patients with middle school education was similar $(47.4 \%$ in ours vs $42.9 \%$ in theirs). Despite this similarity, it should be mentioned that none of the patients in this study were illiterate. ${ }^{14}$ In the present study, history of smoking was recorded in $43.2 \%$ of the patients, almost double than that found by Ketcheson et al. in 2017, where he reported that $27.1 \%$ of the patients undergoing cesarean section smoked..$^{15}$ The most frequent comorbidities were obesity followed by hypertension, similar to the study carried out in England in 2013, where they also associated high BMI, tobacco consumption, chronic hypertension and leukocytosis with an increased risk of wound infection. ${ }^{16}$ On the other hand, in the study conducted in Cuba in 2014, the main comorbidity was anemia, followed by obesity and hypertension. ${ }^{17}$ In a retrospective study done in Finland, obesity, diabetes and a long surgical time were associated with an increased risk of incisional infection. ${ }^{18}$ Similarly, a study in the United States found that the risk factors for SSI with the highest odds ratios were obesity, diabetes and hypertension. ${ }^{19}$ In Mexico, diabetes, hypertension and immune thrombocytopenia were associated with SSIs in $6.9 \%, 4.1 \%$ and $1.3 \%$ respectively. ${ }^{13} 5.3 \%$ of the participants in the study had some type of cancer, lower than study of Vargas et al. ${ }^{20}$ conducted in Mexico City in 2016, who had a prevalence of $17.1 \%$. Also, about three quarters (12.8\%) of these patients were readmitted for SSI, making it the main cause of reentry for this population. ${ }^{20}$ The time of year with the highest number of SSI was the fall, compared to the multicentric study by Durkin et al., who concluded that SSI rates were higher during summer months. ${ }^{9}$ The surgical site of greater frequency of infection was in the abdomen in $81.1 \%$, which coincides with a review article in which the two most common procedures were abdominal hysterectomy and cesarean section; surgical wound infection rates were $3.0-12.2 \%$ and $1.8-11.3 \%$, respectively. ${ }^{21}$ Finally, it was calculated that the average hospital stay was 4.5 days, much less than that found in a study conducted in Africa, where they reported that the average hospital stay of these patients was 15.5 days. They also concluded that the duration of hospitalization was a risk factor for surgical wound infection. ${ }^{12}$

\section{Conclusion}

Obesity and hypertension were the most frequent comorbidities associated with surgical wound infection, similar to that reported at the international and national levels. Therefore, in primary care, it is very important to identify the patients with existing comorbidities who are going to be subjected to a programmed surgical procedure. They should be sent to the nutrition and social work services, as well as adequately control their comorbidities (glucose levels, blood pressure, or treatment adjustments) to avoid the risk of SSIs. Support networks should also be promoted, informing them of the importance of postoperative care and doctor's indications upon discharge, as well as their follow-up appointments with the obstetrics \& gynecology and family medicine departments.

\section{Acknowledgments}

None.

\section{Conflicts of interest}

The author declares there is no conflict of interest.

\section{References}

1. Prevención, Diagnóstico y Tratamiento de la Infección en Herida Quirúrgica Post cesárea en los tres niveles de atención, Guías de Práctica
Clínica. Mexico: Secretaría de Salud; 2011. p. 1-33.

2. Berríos S, Umscheid C, Bratzler D, et al. Centers for Disease Control and Prevention Guideline for the Prevention of Surgical Site Infection, 2017. JAMA Surg. 2017;152(8):784-791.

3. López Tagle Y, Hernández Ferrer M, Saldivar Arias T, et al. Infección de la herida quirúrgica Aspectos epidemiológicos. Rev Cubana Med Milit. 2007;36(2):1-11.

4. Intervenciones preventivas para la seguridad en el paciente quirúrgico. Mexico: Secretaría de Salud; 2013.

5. Rajayana Y, Ranaraja S, Sumathipala S. Analyzing the necessity of prophylactic antibiotic usage in laparoscopy for uncomplicated gynecologic conditions in Sri Lanka. J Obstet Gynaecol Res. 2015;41(4):596-600

6. Burillo A, Moreno A, Salas C. Diagnóstico microbiológico de las infecciones de piel $y$ tejidos blandos, 22 $2^{\text {th }}$ edition. Spain: Sociedad Española de Enfermedades Infecciosas y Microbiología Clínica. 2006 p. $1-45$.

7. Lemus-Rocha R, García-Gutiérrez LB, Basavilvazo-Rodríguez MA, et al. Incidencia de herida quirúrgica infectada y profilaxis con cefotaxima en cesárea. Ginecol Obstet Mex. 2005;73(10):43-537.

8. Bravo Villacres J, Soria NC. Determinación de microorganismos causantes de infección del sitio quirúrgico tras cesárea mediante cultivo y su relación con la ruptura prematura de membranas, expulsivo prolongado, y tiempo quirúrgico en el Hospital Gineco-obstétrico Isidro Ayora en el periodo 2014. Equator: Universidad Central del Ecuador. Facultad de Ciencias Médicas. 2015. p. 1-87.

9. Durkin M, Dicks K, Baker A, et al. Seasonal Variation of Common Surgical Site Infections: Does Season Matter? Infect Control Hosp Epidemiol. 2015;36(9):1011-1016

10. Durkin M, Dicks K, Baker A, et al. Postoperative infection in spine surgery: does the month matter? J Neurosurg Spine. 2015;23(1):128-134.

11. Jenks PJ, Laurent M, Mcquarry S, et al. Clinical and economic burden of surgical site infection (SSI) and predicted financial consequences of elimination of SSI from an English hospital. J Hospital Infect. 2014;86(1):24-33.

12. Ngowe M, Toure A, Mouafo Tambo FF, et al. Prevalence and risk factors associated with post-operative infections in the Limbe Regional Hospital of Cameroon. Open Surg J. 2014;8:1-8.

13. Buitrón-García R, López-Delgado M, Basurto-Kuba E, et al. Infección del sitio quirúrgico Experiencia de dos años en el servicio de ginecología y obstetricia del Hospital General de México. Ginecol Obstet Mex. 2006;74(5):260-264.

14. Castro M, Romero A. Factores de riesgo asociados a infección de heridas quirúrgicas en colecistectomía abierta electiva. Salud en Tabasco. 2010;16(1):869-874

15. Ketcheson F, Woolcoot C, Allen V, et al. Risk factors for surgical site infection following cesarean delivery: a retrospective cohort study. CMAJ Open. 2017;5(3):E546-E556.

16. Dotters-Katz SK, Feldman C, Puechl A, et al. Risk factors for postoperative wound infection in the setting of chorioamnionitis and cesarean delivery. J Matern Fetal Neonatal Med. 2016;29(10):1541-1545.

17. Frías-Chang NV, Begué-Dalmau N, Martí-Rodríguez LA, et al. Infección del sitio quirúrgico post cesárea. MEDISAN. 2016;20(5):593-603.

18. Shintaro Y, Masaki K, Noriko K, et al. Identification of new risk factors for wound separation in gynecologic malignancy surgery. $J$ Obstet Gynaecol Res. 2015;41(1):107-113.

19. Subramaniam A, Jauk VC, Figueroa D, et al. Risk factors for wound 
disruption following cesarean delivery. J Matern Fetal Neonatal Med. 2014;27(12):1237-1240.

20. Vargas-Lejarza S, Villagra-Blanco V. Análisis de causas de reingreso en pacientes histerectomizadas. Acta Med Costarric. 2016; 58(1): 27-31.
21. Stanirowski PJ, Wnuk A, Cendrowski K, et al. Growth factors, silver dressings and negative pressure wound therapy in the management of hard-to-heal postoperative wounds in obstetrics and gynecology: a review. Arch Gynecol Obstet. 2015;292(1):757-775. 